\title{
Urinary Tract Infections Presenting with Jaundice
}

\author{
S. H. NG and J. R. RAWSTRON* \\ From the Paediatric Department, King's College Hospital and Belgrave Hospital for Children, London
}

\begin{abstract}
Ng, S. H., and Rawstron, J. R. (1971). Archives of Disease in Childhood, 46, 173. Urinary tract infections presenting with jaundice. Six cases are presented in which jaundice was the prominent feature in acute urinary tract infection. 4 of the 6 cases had positive blood cultures. The source of the infection could not be traced, but all were male infants of social grade $\mathrm{V}$ families, and poor hygiene was a common factor. Appropriate antibiotics were given early in the course of the disease, and the infection and jaundice cleared; there were no sequelae. The jaundice was due mainly to hepatocellular impairment, with varying degrees of haemolysis and cholestasis. A comprehensive bacteriological examination is recommended in any case presenting with jaundice and pyrexia.
\end{abstract}

Acute urinary tract infection in infancy may present problems in diagnosis. The classical picture is of fever, failure to gain weight, and anorexia; bacteriological examination of the urine is conclusive. On occasion, however, the most prominent feature is jaundice. This may divert the physician's attention to hepatic or haematological disturbances and so delay the institution of chemotherapy. In many of these cases the urinary tract infection has progressed to septicaemia before the nature of the disease is recognized, and the delay in starting chemotherapy may have serious consequences.

We describe 6 cases of acute urinary tract infection, presenting with jaundice in a Casualty Department. All were seen in the spring and summer of 1965. Appropriate chemotherapy was followed by resolution of the infection and of the jaundice, and no sequelae were found at follow-up.

\section{Case Reports}

Case 1. A 2-week-old male West Indian infant was brought to hospital with a history of increasing jaundice for the previous three days, poor feeding, and crying. He was born at term, and his birthweight was $3.32 \mathrm{~kg}$. Examination showed pallor in addition to jaundice; the pulse rate was 140 per minute; the liver was enlarged $2 \mathrm{~cm}$ below the costal margin but there were no other abormal physical signs.

Direct serum bilirubin $19.5 \mathrm{mg} / 100 \mathrm{ml}$; total bilirubin $33.0 \mathrm{mg} / 100 \mathrm{ml}$; alkaline phosphatase $20 \mathrm{KA}$ units/ $100 \mathrm{ml} ; \mathrm{Hb} 10.5 \mathrm{~g} / 100 \mathrm{ml}$; white cell count $18,000 /$

Received 2 October 1970.

^Present address: Wycombe General Hospital, High Wycombe, Bucks. $\mathrm{mm}^{3}$; sickling test negative; $\mathrm{Hb}$ electrophoresis showed $\mathrm{Hb}$ C trait; direct Coombs test negative. Peripheral blood film-red cells showed 'target' cell change; a neutrophil excess with a left shift; normal platelets. No pathogens were isolated from a rectal swab. Urine contained pus cells + , and culture showed a heavy growth of Escherichia coli sensitive to tetracycline, chloramphenicol, streptomycin, and neomycin. Blood culture yielded a pure growth of Esch. coli with a similar pattern of antibiotic sensitivity.

Tetracycline and streptomycin were given intramuscularly, and the temperature returned to normal. The child began to put on weight, but the bilirubin rose to $42 \mathrm{mg} / 100 \mathrm{ml}$ and the blood urea at this stage was $66 \mathrm{mg} / 100 \mathrm{ml}$. The next day the bilirubin level began to fall, and was normal after 17 days. $\mathrm{Hb}$ fell to $7.0 \mathrm{~g} / 100 \mathrm{ml}$ by the eighth day after admission, but transfusion of $120 \mathrm{ml}$ blood raisea it to $15 \cdot 5 \mathrm{~g} / 100 \mathrm{ml}$. 16 days after admission blood and urine cultures were sterile. An intravenous pyelogram was performed after clinical recovery and showed no abnormality.

Case 2. A 7-week-old male West Indian infant was brought to the Casualty Department with a history of having passed dark urine for the previous two weeks. He had also passed pale yellow offensive stools. Delivery had been normal, at term, and his birthweight was $3.32 \mathrm{~kg}$. Examination showed an ill-looking infant with listlessness, cough, and deep jaundice. The liver was enlarged $3 \mathrm{~cm}$ below the costal margin.

Direct serum bilirubin $8.8 \mathrm{mg} / 100 \mathrm{ml}$; total bilirubin $13.5 \mathrm{mg} / 100 \mathrm{ml}$; alkaline phosphatase $41 \mathrm{KA}$ units/ $100 \mathrm{ml}$; total protein $5.0 \mathrm{~g} / 100 \mathrm{ml}$; blood urea $64 \mathrm{mg} /$ $100 \mathrm{ml} ; \mathrm{Hb} 8 \cdot 2 \mathrm{~g} / 100 \mathrm{ml}$; PCV 24; MCHC $34 \%$; white cell count 13,000 per $\mathrm{mm}^{3}$; direct Coombs test negative. Peripheral blood film-well haemoglobinized red cells with mild 'target' cell change; mild polychromasia with 
occasional nucleated red cells and some distorted and 'burr' forms; haemoglobin electrophoresis showed sickle-cell trait; moderate neutrophil 'left shift'; mild reduction in platelets. Stools showed \pm fat globules on microscopy, and tryptic activity was normal. Urine contained bilirubin ++ and protein ++ ; white cells +++ ; culture yielded a heavy growth of paracolon bacilli, sensitive to ampicillin, tetracycline, chloramphenicol, and streptomycin. Blood culture yielded a pure growth of paracolon bacilli with a similar pattern of antibiotic sensitivity.

The infant was given tetracycline and responded rapidly. The serum bilirubin was normal eight days after admission, and the urine was sterile. An intravenous pyelogram was performed after clinical recovery and was normal.

Case 3. A 12-year-old Anglo-Chinese male infant was transferred from a British Army Hospital in Germany to King's College Hospital. He was born at term and his birthweight was $4.54 \mathrm{~kg}$. 6 days after birth he began to vomit, and was reluctant to feed. 3 days later he developed haematuria and was admitted to hospital. Urine showed gross albuminuria and large numbers of pus cells; culture yielded Esch. coli, sensitive to ampicillin and chloramphenicol. His blood urea was $150 \mathrm{mg} / 100 \mathrm{ml}$ and he looked jaundiced. He was given ampicillin and chloramphenicol; his blood urea rose to $230 \mathrm{mg} / 100 \mathrm{ml}$ and he developed hyperkalaemia for which he was given Resonium $\mathrm{A}$ and insulin. The day before transfer to King's College Hospital he had several generalized convulsions.

On examination he looked very ill, jaundiced, and dehydrated; the liver was enlarged $5 \mathrm{~cm}$ below the costal margin and the umbilicus was 'sticky'. Opisthotonus was present, with marked neck stiffness and a bulging anterior fontanelle; the limbs were hypertonic.

Total serum bilirubin $9.6 \mathrm{mg} / 100 \mathrm{ml}$; blood urea $240 \mathrm{mg} / 100 \mathrm{ml}$; plasma $\mathrm{Na} 120 \mathrm{mEq} / 1$.; plasma K $5 \cdot 8$ $\mathrm{mEq} / 1$., alkali reserve less than $5 \mathrm{mEq} / \mathrm{l}$.; blood $\mathrm{pH} 7 \cdot 18$; Hb $17 \cdot 2 \mathrm{~g} / 100 \mathrm{ml}$; PCV 55; MCHC $31 \%$; white cell count $30,000 / \mathrm{mm}^{3}$. Peripheral blood film-normochromic red cells with many 'burr' forms; neutrophil leucocytosis with intense toxic granulation. Urine contained pus cells +++ , and culture yielded a heavy growth of Esch. coli, sensitive to ampicillin and chloramphenicol, but resistant to tetracycline and sulphonamides. Blood culture yielded Esch. coli with a similar pattern of antibiotic sensitivity. A swab from the umbilicus was sterile. Lumbar puncture showed slightly xanthochromic fluid, protein $40 \mathrm{mg} / 100 \mathrm{ml}$, no increase in white cells, and sterile.

Ampicillin and chloramphenicol were continued; sodium bicarbonate was added to an intravenous drip and the blood $p \mathrm{H}$ brought to 7.31. He became pyrexial as his hydration improved, but this returned to normal after 5 days. His blood urea, serum bilirubin, and urine culture were normal after 10 days.

An intravenous pyelogram was performed a month after his recovery and was normal. He was seen again at 5 months and appeared normal mentally.
Case 4. A 6-week-old Irish male infant was admitted with a history of passing yellow offensive stools for the previous 5 days, and of pallor and jaundice for 3 days. He was born at term and his birthweight was $3.60 \mathrm{~kg}$. He did not take feeds well, and cried often. On examination he was pale and jaundiced; the liver was enlarged $3 \mathrm{~cm}$ below the costal margin, and there was coronal hypospadias.

Direct serum bilirubin $2.5 \mathrm{mg} / 100 \mathrm{ml}$; total bilirubin $3.5 \mathrm{mg} / 100 \mathrm{ml}$; blood urea $63 \mathrm{mg} / 100 \mathrm{ml}$; plasma $\mathrm{Na}$ $130 \mathrm{mEq} / 1$.; plasma K $5.4 \mathrm{mEq} / \mathrm{l}$; $\mathrm{Hb} 5 \cdot 8 \mathrm{~g} / 100 \mathrm{ml}$. PCV 20; MCHC $30 \%$; reticulocytes $2 \cdot 8 \%$; screen fragility test normal; white cell count $24,800 / \mathrm{mm}^{3}$ Peripheral blood film-marked anisocytosis of red cells with microspherocytosis, polychromasia and occasional nucleated red cells; some distorted 'helmet' and 'burr' cells seen; toxic neutrophil 'left shift'; platelets reduced; direct Coombs test negative. Urine contained protein + and pus cells +++ ; culture yielded a heavy growth of Esch. coli, sensitive to ampicillin and tetracycline.

$\mathrm{He}$ was given tetracycline and ampicillin and the temperature settled rapidly. The blood urea and bilirubin fell, and he had a reticulocyte response of $40 \%$ which was followed by a rise in $\mathrm{Hb}$ to $9.0 \mathrm{~g} / 100 \mathrm{ml}$. The urine became sterile 10 days after treatment.

Intravenous pyelogram was performed three months after recovery and was normal.

Case 5. An 8-week-old West Indian male infant was admitted because of crying between feeds, dark urine, and increasing jaundice. He was born at term and the birthweight was $3.04 \mathrm{~kg}$. Examination showed a pyrexial, listless, ill child, with jaundice and pallor. Some rales were heard at both lung bases. The liver was not palpable.

Direct serum bilirubin $20.5 \mathrm{mg} / 100 \mathrm{ml}$; total bilirubin $30.0 \mathrm{mg} / 100 \mathrm{ml}$; blood urea $89 \mathrm{mg} / 100 \mathrm{ml}$; Hb $6.7 \mathrm{~g} /$ $100 \mathrm{ml}$; reticulocytes $2.6 \%$; ESR $58 \mathrm{~mm} / \mathrm{hr}$; white cell count $28300 / \mathrm{mm}^{3}$; test for sickling negative. Peripheral blood film-anisocytosis of red cells with mild polychromasia, spherocytosis, distorted 'helmet' and 'burr' forms, and occasional nucleated red cells; neutrophil leucocytosis with toxic 'left shift'. Urine contained protein ++ and pus cells +++ ; culture yielded a heavy growth of Esch. coli, sensitive to tetracycline, streptomycin, and ampicillin. Blood culture yielded Esch. coli with a similar pattern of antibiotic sensitivity.

Tetracycline was given orally and the infant's condition improved. The temperature was normal by the third day, and $\mathrm{Hb}$ rose after a good reticulocyte response. The blood urea and bilirubin levels were normal after two weeks. The urinary infection persisted, however, and urine examination after 12 days showed pus cells ++ with Esch. coli and Proteus resistant to tetracycline. This infection responded well to ampicillin and the urine was sterile 7 days later.

Intravenous pyelography was performed after clinical recovery and showed no abnormality.

Case 6. A 6-week-old Nigerian male infant was 
admitted with a history of pyrexia and passing darkcoloured urine. $\mathrm{He}$ was born at 44 weeks' gestation and the birthweight was $3.38 \mathrm{~kg}$. Examination showed a jaundiced, afebrile infant. The liver was palpable $2 \mathrm{~cm}$ below the costal margin.

Direct serum bilirubin $5.4 \mathrm{mg} / 100 \mathrm{ml}$; total bilirubin $7.5 \mathrm{mg} / 100 \mathrm{ml}$; alkaline phosphatase $25 \mathrm{KA}$ units/ $100 \mathrm{ml}$; blood urea $42 \mathrm{mg} / 100 \mathrm{ml}$; Hb $7.6 \mathrm{~g} / 100 \mathrm{ml}$; PCV 26; MCHC $29 \%$; white cell count $28,000 / \mathrm{mm}^{3}$; direct Coombs test negative; test for sickling negative; $\mathrm{Hb}$ electrophoresis showed $10 \% \mathrm{Hb}-\mathrm{S}, 20 \% \mathrm{Hb}-\mathrm{A}$, and $70 \% \mathrm{Hb}-\mathrm{F}$ (confirmed at a later date as a sickle-cell trait). Peripheral blood film: mild anisocytosis and hypochromia of red cells; neutrophil leucocytosis with moderate 'left shift'. Urine contained protein + and pus cells + ; bilirubin +++ ; culture yielded $E s c h$. coli sensitive to tetracycline and chloramphenicol, and Streptococcus faecalis.

Tetracycline was given orally, and the jaundice gradually subsided. The infant began to feed well, and gained weight. The urine was sterile 4 weeks after admission. $\mathrm{Hb}$ rose to $10 \cdot 2 \mathrm{~g} / 100 \mathrm{ml} 8$ weeks after admission.

An intravenous pyelogram was performed two months after recovery, and showed no abnormality.

The clinical data are summarized in Table $I$, and the relevant laboratory data are given in Table II.

\section{Discussion}

Our six cases presented in a short period of six months and no further examples have been seen. Similar 'outbreaks' have been described in America (Sweet and Wolinsky, 1964; Kenny et al., 1966; and Seeler and Hahn, 1969). Five of our cases came from the same area (Borough of Lambeth) but born in different hospitals, and one came from North Germany. Detailed serological studies were not available, but it is unlikely that the same strain of Esch. coli was responsible for infection in the five cases from which it was isolated.

The source of the infection was not apparent. One infant had a 'sticky' umbilicus, but a swab from this yielded no growth. One had coronal hypospadias which did not interfere with micturition. Common factors were that they were male, and all were of immigrant parents in social grade $\mathrm{V}$. Poor elementary hygiene may thus be a predisposing factor. Other workers have also been unable to show the source of infection (Bernstein and Brown, 1962; Hamilton and Sass-Kortsak, 1963), though Arthur and Wilson (1967) were able to exclude umbilical sepsis as the cause. Each infant in our series had an intravenous pyelogram performed after clinical recovery, and no malformation of the urinary tract was evident. Bernstein and Brown (1962) described seven cases of pyelonephritis with jaundice, and found no underlying genitourinary tract malformation at necropsy.

The cause of the jaundice has been variously ascribed to haemolysis (Hamilton and Sass-Kortsak, 1963; Seeler and Hahn, 1969) often necessitating transfusion, toxic hepatitis (Seeler and Hahn, 1969), and cholestasis (Arthur and Wilson, 1967). Haemolysis was prominent in three of our cases, as shown by a low $\mathrm{Hb}$ level and a peripheral blood film with polychromasia, spherocytosis, 'burr' cells, and nucleated red cells. The appearance of some blood films was similar to that seen in the haemolyticuraemic syndrome. The direct Coombs test was negative, osmotic fragility test normal, and G6PD in the normal range in these three infants. Blood transfusion was only required in Case 1 , and the

TABLE I

Clinical Data from Six Infants with Jaundice and Acute Urinary Tract Infection

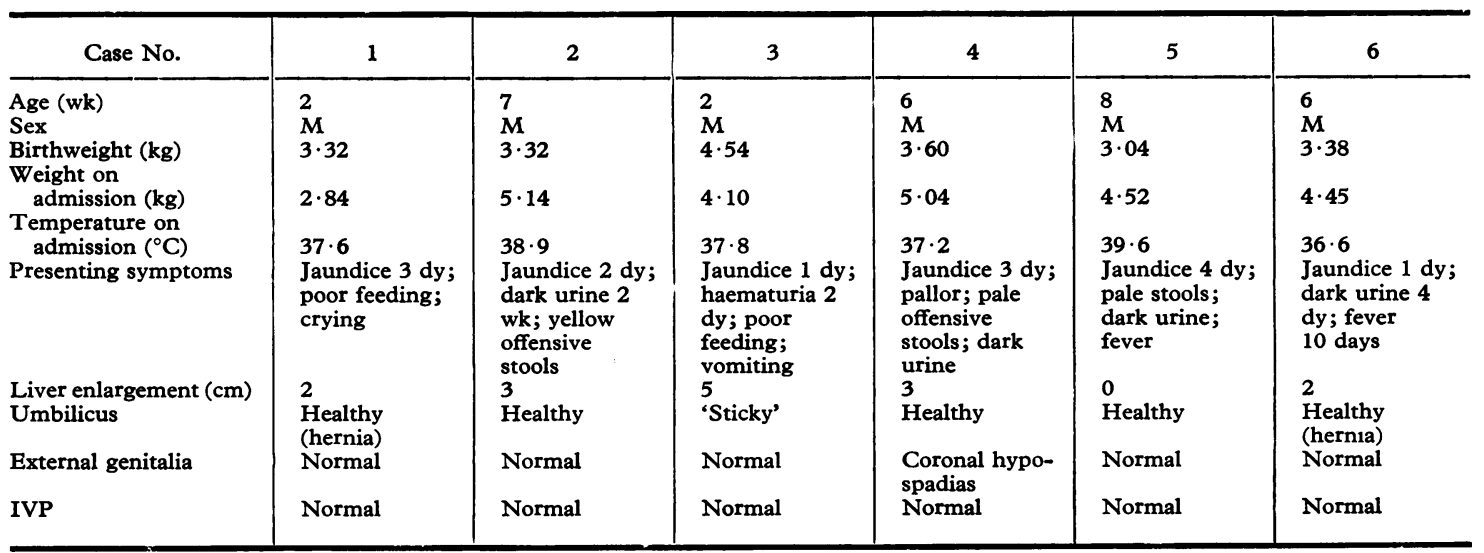


TABLE II

Laboratory Data from Six Infants with Jaundice and Acute Urinary Tract Infection

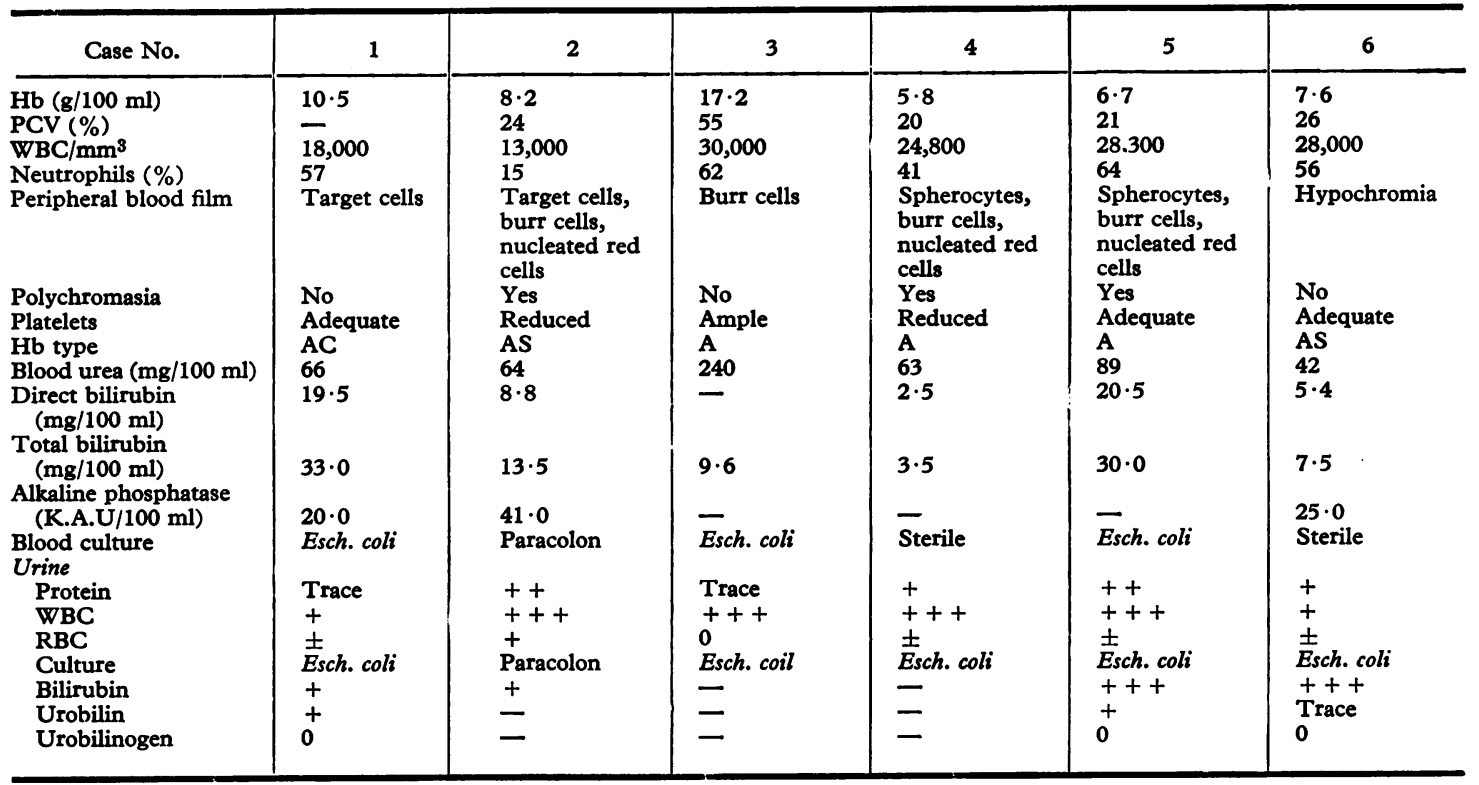

anaemia in the other two improved after resolution of the infection.

Cholestasis was not an important factor, but hepatocellular impairment was present in each case in varying degree. The rapid clearing of the jaundice with antibiotic therapy suggests some form of 'hepatotoxin' formed by the Gram-negative bacilli which produces the toxic hepatitis and contributes to the haemolytic process (Hamilton and Sass-Kortsak, 1963).

Several deaths were reported in earlier series (Bernstein and Brown, 1962; Hamilton and SassKortsak, 1963; Kenny et al., 1966), but none was seen by Arthur and Wilson (1967) or in our own series. This change is probably due to improvements in antibiotic therapy, and to its institution earlier in the course of the disease.

We stress the early recognition of urinary tract infection with renal impairment in this condition. One case was transferred to this hospital for renal dialysis before the true nature of the disease was discovered. Initial examination of the urine from each infant showed pyuria, with infection by Gram-negative bacilli (Esch. coli or paracolon), and in four infants a similar organism was isolated from blood culture. Jaundice, however obvious a feature, should not be allowed to divert attention from any other signs and symptoms which indicate infection. In infants presenting with jaundice and pyrexia, urinalysis and blood culture are of prime importance in the recognition of any underlying in fective process.

We wish to thank Dr. Mary J. Wilmers and Professor C. Eric Stroud for permission to report their cases.

\section{REFERENCES}

Arthur, A. B., and Wilson, B. D. R. (1967). Urinary infection presenting with jaundice. British Medical fournal, 1, 539.

Bernstein, J., and Brown, A. K. (1962). Sepsis and jaundice in early infancy. Pediatrics, 29, 873.

Hamilton, J. R., and Sass-Kortsak, A. (1963). Jaundice associated with severe bacterial infection in young infants. fournal of Pediatrics, 63, 121.

Kenny, J. F., Medearis, D. N. Jr., Klein, S. W., Drachman, R. H., and Gibson, L. E. (1966). An outbreak of urinary tract infections and septicaemia due to Escherichia coli in male infants. Fournal of Pediatrics, 68, 530.

Seeler, R. A., and Hahn, K. (1969). Jaundice in urinary tract infection in infancy. American Fournal of Diseases of Children, $118,553$.

Sweet, A. Y., and Wollusky, E. (1964). An outbreak of urinary tract and other infections due to $E$. coli. Pediatrics, 33, 865 .

Correspondence to Dr. S. H. Ng, Department of Child Health, King's College Hospital, London S.E.5. 